\title{
Imbalance of the interleukin 2 system in children with IDDM
}

\author{
T. Tomoda, T.Kurashige, T. Taniguchi \\ Department of Pediatrics, and Medical Research Laboratory, Kochi Medical School, Nankoku, Kochi, Japan
}

Summary The IL-2 system which involves IL-2 production, IL-2 receptor expression, and response to IL-2, is associated with autoimmune phenomena. Immunological abnormalities including autoimmune phenomena are believed to contribute to the pathogenesis of IDDM. In this study, the production of IL-2, the responses to IL2 and IL-2 receptor expression by peripheral blood $T$ lymphocytes were compared in IDDM and normal non-diabetic children. The percentage of IL-2 receptorpositive circulating $T$ cells was significantly increased in diabetic children, although IL-2 receptor expression induced by con A stimulation did not differ in the diabetic and control children. IL-2 production was significantly decreased in diabetic children compared with the control children. The response of stimulated T cells to IL-2 did not differ in IDDM and control children. In IDDM, IL-2 production by CD4-positive T lymphocytes within the IL-2 system is thought to be selectively defective. On the other hand, IL-4, which is also produced by CD4positive T lymphocytes, was increased. Since IL-4 did not suppress IL-2 production, it would seem that the IL2 producing subset in $\mathrm{CD}^{+}{ }^{+} \mathrm{HLA}-\mathrm{DR}^{+} \mathrm{T}$ cells is decreased in IDDM. These results suggest that in recent onset IDDM, IL-2 receptor-positive circulating T cells require an IL-2 supply.[Diabetologia (1994) 37: 476482]

Key words IDDM, interleukin 2 system, interleukin 4, $\mathrm{T}$ helper 1 and 2
The pathogenesis of IDDM remains obscure and differences in the incidence of this disease among ethnic groups are difficult to interpret $[1,2]$. Whether these ethnic differences are genetic or environmental remains unknown. The lower frequency of a gene uniquely associated with IDDM has been suggested as an explanation for the low incidence among Japanese compared with Caucasians [3]. However, since the discovery of ICA [4-6], immunological abnormalities are

Received: 13 August 1993

and in revised form: 23 November 1993

Corresponding author: Dr. T. Tomoda, Department of Pediatries, Kochi Medical School, Oko-cho, Nankoku, Kochi 783, Japan

Abbreviations: IDDM, insulin-dependent diabetes mellitus; IL, interleukin; con A, concanavalin A; PMNC, peripheral mononuclear cells; ICA, islet cell antibody. now believed to contribute to the pathogenesis of IDDM, regardless of factors related to ethnic differences. The presence of immunological abnormalities involving autoimmune phenomena in IDDM suggests that $\mathrm{T}$ lymphocytes might play an important role in the pathogenesis of this disease [7].

The IL-2 system, which includes IL-2 production, IL-2 receptor expression, and response to IL-2, plays an essential role in $\mathrm{T}$ cell proliferation $[8]$ and differentiation $[9,10]$. We therefore measured these parameters of the IL-2 system to determine whether the immunological abnormalities associated with IDDM were related to the function of this system. It has been reported $[11,12]$ that IL-2 synthesis is decreased in patients with IDDM: IL-2 receptor expression and response to IL-2 have not, however, been studied in these patients. We therefore made simultaneous measurements of these parameters in IDDM children and compared them with results obtained from normal nondiabetic children. The mechanisms responsible for the 
Table 1. Lymphocyte subsets in IDDM and control children

\begin{tabular}{llllll}
\hline & CD3 & CD4 & CD8 & CD25 & HLA-DR \\
\hline Control & $70.9 \pm 4.9$ & $37.8 \pm 9.1$ & $28.4 \pm 7.9$ & $1.8 \pm 0.5^{\mathrm{a}}$ & $1.6 \pm 0.5^{\mathrm{b}}$ \\
IDDM & $69.0 \pm 7.0$ & $41.2 \pm 5.8$ & $29.3 \pm 5.4$ & $4.8 \pm 1.1$ & $2.1 \pm 0.6$ \\
\hline
\end{tabular}

FACS analysis of PMNC from healthy control $(n=37)$ and IDDM $(n=37)$ children. The results are expressed as the percentage of positive cells. Each value represent the mean $\pm \mathrm{SD} .{ }^{\mathrm{a}} p<0.001,{ }^{\mathrm{b}} p<0.01$ vs IDDM children
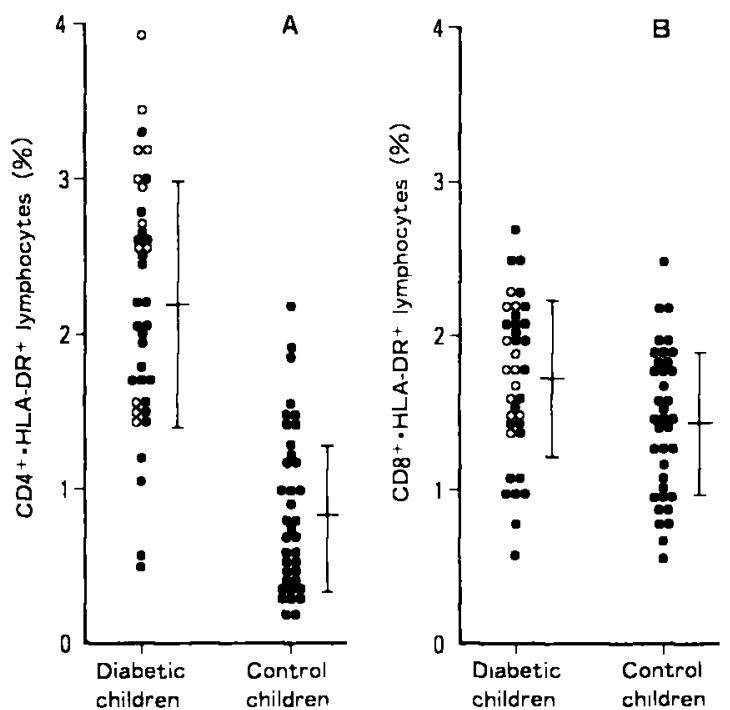

Fig.1A, B. Flow cytometric two-colour analysis of HLA-DR antigen expression on T cells from IDDM $(n=37)$ and normal control children $(n=37)$. Open circles represent diabetic children in whom the duration of the disease was less than 1 year $(n=12)$. The results are expressed as percentages of positive cells. Vertical lines and bars are means \pm SD. (A, CD4; B, CD8)

suppression of IL-2 production have also been considered.

\section{Subjects and methods}

\section{Subjects}

Thirty-seven Japanese IDDM children ( 22 females, 15 males, aged 3 to 18 years, mean 11.7 years) and 37 age- and sexmatched healthy Japanese children ( 22 females, 15 males, aged 4 to 16 , mean 11.2 years) were enrolled in this study. All patients had the classic symptoms and history of IDDM: acute onset, lack of obesity, and an absolute requirement for exogenous insulin. No other clinically evident autoimmune disease was present in the study subjects. The IDDM children were divided into four groups according to the duration of disease: up to 1 year $(n=12), 1$ to 3 years $(n=7), 3$ to 5 years $(n=6)$, and more than 5 years $(n=12)$. Twelve of these children were ICA-positive; 8 of them were newly diagnosed (within 1 year) with IDDM. Informed consent was given by the parents of all subjects and the study was approved by the hospital ethics committee.

\section{Cell separation}

PMNC were separated from heparinized venous blood by FicollIsopaque (Pharmacia, Uppsala, Sweden) density gradient centrifugation.

\section{Lymphocyte subsets}

The cells were stained with monoclonal antibodies using standard immunofluorescence procedures. For single-colour analysis, the antibodies used were labelled with fluorescein, and for twocolour analysis they were labelled with fluorescein or phycoerythrin. $T$ cell subsets were identified with the monoclonal antibodies, CD3, CD4, CD8 (OKT3, OKT4, OKT8: Ortho, Raritan, NJ, USA), CD25 (anti-IL-2 receptor), and HLA-DR (BectonDickinson, Sunnyvale, Calif., USA).

Lymphocyte subsets were quantified by flow cytometry (JASCO FCM-1D cell sorter, Japan Spectroscopic Co. Ltd., Tokyo, Japan). The background fluorescence profile was subtracted from each sample. For each analysis, we used $2 \times$ $10^{5}$ cells.

To induce IL-2 receptors, PMNC, at a final concentration of $1 \times 10^{6}$ lymphocytes/ml in RPMI 1640 culture medium supplemented with $10 \%$ fetal calf serum, were stimulated with various concentrations of con A (E.Y. Laboratory, San Mateo, Calif., USA) in $5 \% \mathrm{CO}_{2}$ at $37^{\circ} \mathrm{C}$. Following stimulation, the presence of IL-2 receptors was tested for as described above, using the CD25 monoclonal antibody.

\section{$I L-2$ and IFN- $\gamma$ production}

PMNC were cultured as described above for IL-2 receptor induction in the presence of $5 \mu \mathrm{g} / \mathrm{ml}$ con A. After $24 \mathrm{~h}$, the supernatant was removed and assayed for IL-2 production, and the cells were prepared for testing the response to IL-2. The quantity of IL-2 produced by con A-stimulated lymphocytes was determined by measuring the ability to induce $\left[6-{ }^{3} \mathrm{H}\right]$-thymidine (specific activity $19.3 \mathrm{Ci} / \mathrm{nmol}$ : New England Nuclear, Boston, Mass., USA) uptake in murine IL-2-dependent T lymphocytes [13]. Long-term cultured IL-2-dependent cells were a gift of Shionogi Company (Osaka, Japan). To confirm production of the IL-2 molecule, an ELISA (Genzyme Co., Boston, Mass., USA) was also performed; this was done according to the manufacturer's instructions, except in the case of standard IL-2 (same r-IL-2 used in bioassay). Units of IL-2 activity were determined using recombinant human IL-2 (r-IL-2: Shionogi Co.) as a standard. IFN- $\gamma$ in the same specimen, was also measured with an ELISA (Genzyme Co.).

\section{Response to $I L-2$}

The cultured cells described above were washed three times with phosphate-buffered saline supplemented with $10 \mathrm{mg} / \mathrm{ml} \alpha$ methyl-D-mannoside (Sigma, St. Louis, Mo., USA) and cultured at a final concentration of $5 \times 10^{5}$ lymphocytes $/ \mathrm{ml}$, in RPMI 1640 culture medium supplemented with $10 \%$ fetal calf serum and $10 \mathrm{mg} / \mathrm{ml} \alpha$-methyl-D-mannoside, with or without $\mathrm{r}$-IL-2. At the times indicated, $12.5 \mu \mathrm{Ci} / \mathrm{ml}$ of $\left[6-{ }^{3} \mathrm{H}\right]$-thymidine was added, and the amount of radioactivity incorporated into the cells was deter- 
Table 2. IL-2 receptor expression on $\mathrm{T}$ lymphocytes by con A stimulation

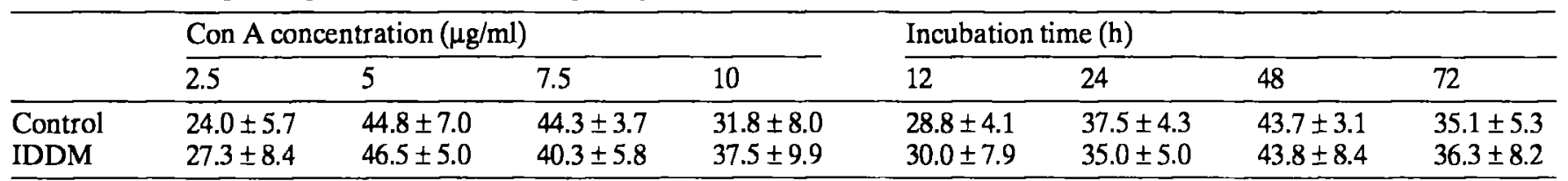

FACS analysis of PMNC from healthy control $(n=8)$ and IDDM $(n=8)$ children. For dose-response experiments PMNC were cultured in the presence of indicated dose of con $A$ for $48 \mathrm{~h}$, and for time course experiments PMNC were cultured in the

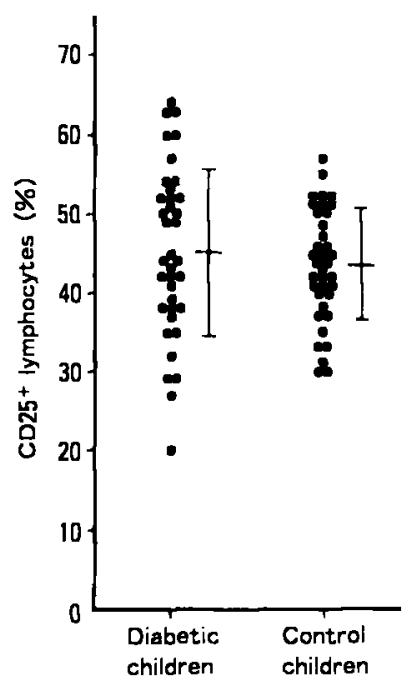

Fig. 2. Flow cytometric analysis of CD25 (IL-2 receptor) expression on PMNC of $\operatorname{IDDM}(n=37)$ and control children $(n=37)$ induced by con A stimulation. Vertical lines and bars are means $\pm \mathrm{SD}$, respectively

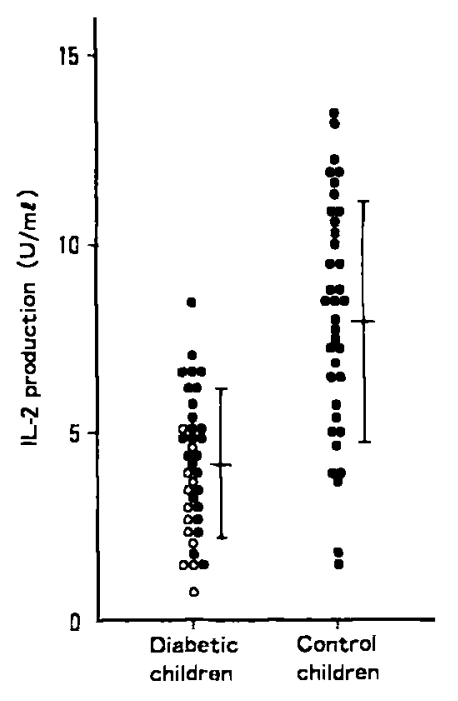

Fig. 3. Comparison of IL-2 production in IDDM $(n=37)$ and normal control children $(n=37)$ using bioassay. Open circles represent diabetic children in whom the duration of the disease was less than 1 year $(n=12)$. Vertical lines and bars are means $\pm \mathrm{SD}$

mined after an 8-h incubation. The response to IL-2 was calculated as the $\left[6-{ }^{3} \mathrm{H}\right]$-thymidine uptake following culture with $\mathrm{r}$-IL2 minus that without $r-$ IL-2 culture.

\section{IL-4 production}

PMNC were cultured as described above for IL-2 receptor induction in the presence of $5 \mu \mathrm{g} / \mathrm{ml}$ con A. After $24 \mathrm{~h}$, the supernatant was removed to be assessed for IL-4 production by ELISA (Genzyme Co.). Serum IL-4 was also measured by ELISA (Genzyme Co.). presence of $5 \mu \mathrm{g} / \mathrm{ml}$ con A for indicated times, respectively. The results are expressed as the percentage of IL-2 receptor positive cells. Each value represents the mean \pm SD from four different preparations

\section{Effect of $r-I L-4$ on IL-2 production}

PMNC from healthy control and IDDM children were cultured with various concentrations of human recombinant IL-4 (r-IL-4: Genzyme Co.) as described for IL-2 receptor induction in the presence of $5 \mu \mathrm{g} / \mathrm{ml}$ con A. After $24 \mathrm{~h}$, the supernatant was removed to be assayed for IL-2 production by ELISA, and the cells were prepared for the RNA blot analysis.

\section{RNA blot hybridization}

Total cellular RNA was extracted from con A-stimulated PMNC by a guanidinium isothiocyanate/cesium chloride ultracentrifugation method [14]. The RNA was denatured and separated on $0.8 \%$ agarose/formaldehyde gel [15]. RNA was then transferred onto a nylon filter and hybridized with a ${ }^{32} \mathrm{P}$ labelled 0.6-kb PstI fragment of the cDNA clone p3-16 from human IL-2 [16] (a gift from Dr. T. Taniguchi, Institute for Molecular and Cellular Biology, Osaka University, Osaka, Japan) and the third exon of human $\beta$-actin [17] (a gift from Dr. T.Noguchi, Department of Nutrition, Medical School, Osaka University) under conditions described previously [18]. The filter was exposed to Kodak XAR-5 film at $-70^{\circ} \mathrm{C}$ with an intensifying screen for $15 \mathrm{~h}$ for IL-2 testing and $5 \mathrm{~h}$ for $\beta$-actin testing. The band intensity was quantified using a Shimazu (Tokyo) dualwavelength TLC scanner, model CS-930.

\section{Statistical analysis}

Results are given as mean \pm SD. The significance of differences between group means was determined using Student's $t$-test. $p$ values of less than 0.05 were considered significant.

\section{Results}

\section{Surface marker analysis}

The proportions of $\mathrm{T}$ cell subsets, defined as the percentage of lymphocytes stained with CD3, CD4, and CD8, respectively, were not different for IDDM and normal control children. However, the percentages of IL-2 receptor and HLA-DR-positive activated T cells was significantly higher $(p<0.001)$ in IDDM children than in the controls (Table 1 ). The activated T cells, as assessed by two-colour analysis, were mostly CD4positive, and in the group in which the duration of the 


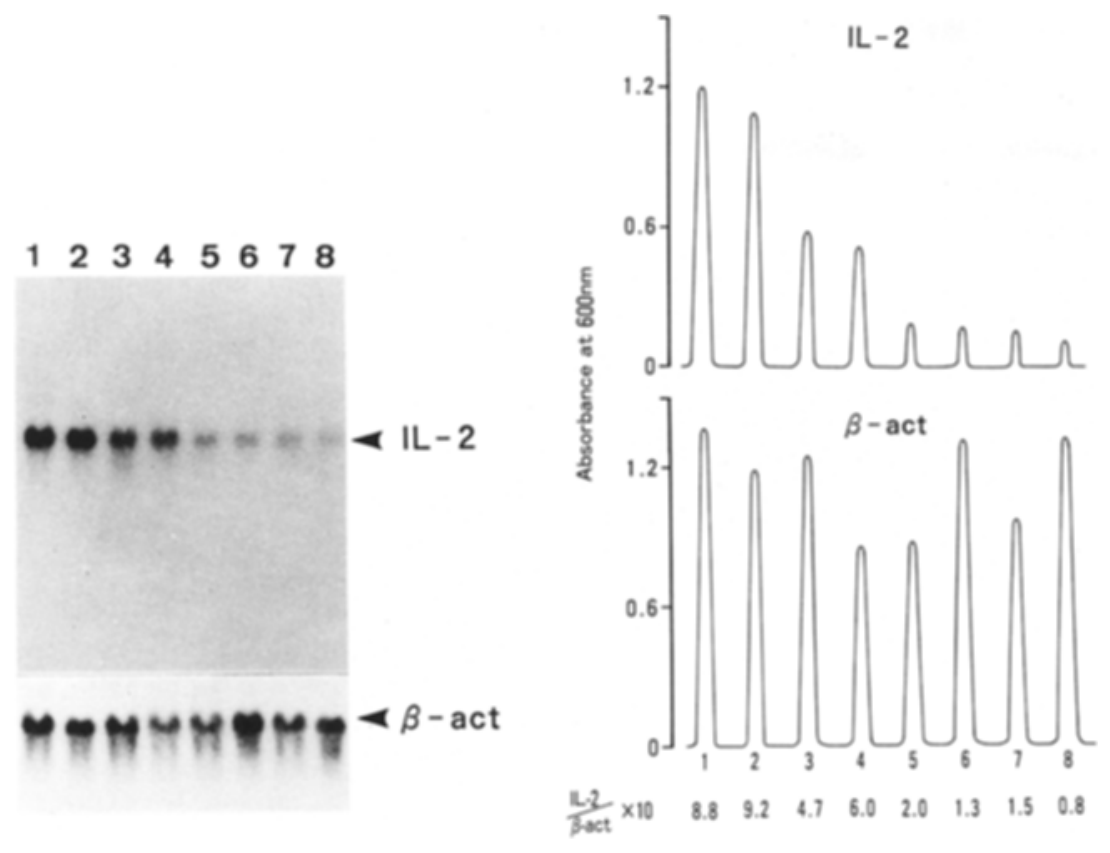

Fig.4. (Left panel) Northern blot analysis of IL2 mRNA expression with con A stimulation in PMNC. Lanes 1-4 represent normal control children and lanes 5-8 represent IDDM children in whom the duration of the disease was less than 1 year. The same filter was also hybridized with $\beta$-actin. (Right panel) Densitometric quantification of the bands. The relative intensity of the bands was densitometrically measured at $600 \mathrm{~nm}$ disease was less than 1 year, $\mathrm{CD}^{+}{ }^{+} \mathrm{HLA}-\mathrm{DR}{ }^{+} \mathrm{T}$ cells were significantly increased compared to the other diabetic groups in which the duration of the disease was more than 1 year (Fig. 1).

IL-2 receptor expression induced by con A stimulation was also studied. To determine the proper experimental conditions, we performed dose-response and time course experiments with con A (Table 2). As summarized in Table 2, the incidence of IL-2 receptor expression was similar for the control and IDDM patients. A dose of $5 \mu \mathrm{g} / \mathrm{ml}$ con A caused a marked increase in the number of IL-2 receptor-positive cells. However, at concentrations of $7.5 \mu \mathrm{g} / \mathrm{ml}$ or higher, con A did not enhance IL-2 receptor expression. Receptor expression increased through the initial $48 \mathrm{~h}$ of incubation. Thus, we selected the $5 \mu \mathrm{g} / \mathrm{ml}$ concentration of con $A$ and a 48-h incubation period for stimulation.

There was no difference between IDDM and control children in IL-2 receptor expression induced by con A stimulation (Fig. 2).

\section{IL-2 and IFN- $\gamma$ production}

Since bioassays for IL-2 can be affected by the presence of synergistically acting cytokines or inhibitory components or both, we measured both the activity and the quantity of IL-2. IL-2 production was significantly and consistently less $(p<0.001)$ in IDDM children than in control children: especially in those children in whom the duration of disease was less than 1 year (Fig.3). There was a close correlation between the results of the bioassay and those of ELISA $(r=0.826, p<0.001$; data not shown). We also tested the gene expression associated with IL-2, and demonstrated a decrease in IL-2
mRNA associated with IDDM (Fig. 4). In IL-2 production, there were no significant differences either between well controlled ( $\mathrm{Hb} \mathrm{A}_{1 \mathrm{c}}<8 \%$ ) and poorly controlled $\left(\mathrm{Hb} \mathrm{A}_{1 \mathrm{c}}>8 \%\right)$ IDDM children or between HLA types (data not shown). IFN- $\gamma$ production showed the same pattern as IL-2 production (IDDM children, $7.2 \pm 3.2 \mathrm{U} / \mathrm{ml}$ vs control children, $15.0 \pm$ $6.2 \mathrm{U} / \mathrm{ml} ; p<0.001)$.

\section{IL-4 production}

It has been suggested that the production of IL-2 is closely related to that of IL-4. We therefore studied IL-4 production by PMNC in both IDDM and control children. Although there was no difference in IL-4 levels between the IDDM and normal control children, IL-4 production stimulated by con A was significantly increased in IDDM $(p<0.001)$ (Fig.5).

\section{Effect of IL-4 on IL-2 production}

To clarify whether IL-4 affected IL-2 synthesis, we studied the effect of r-IL- 4 on the IL-2 production induced by con A stimulation. IL-4 did not suppress this IL-2 production (Fig. 6).

\section{Response to IL-2}

The response of stimulated T lymphocytes to IL-2 was also studied. To determine the IL-2 concentration to be used, we performed dose-response experiments (Table 3). As the concentration of IL-2 was increased to $25 \mathrm{U} / \mathrm{ml}$, T lymphocyte proliferation was observed; 

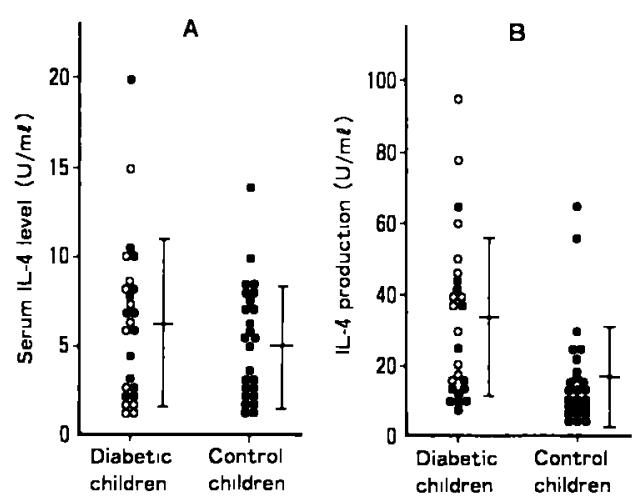

Fig. 5A, B. Comparison of serum IL-4 levels (A) and IL-4 production induced by con A stimulation (B) in IDDM $(n=25)$ and control children $(n=25)$. Open circles represent diabetic children in whom the duration of the disease was less than 1 year $(n=12)$. Vertical lines and bars are means $\pm \mathrm{SD}$

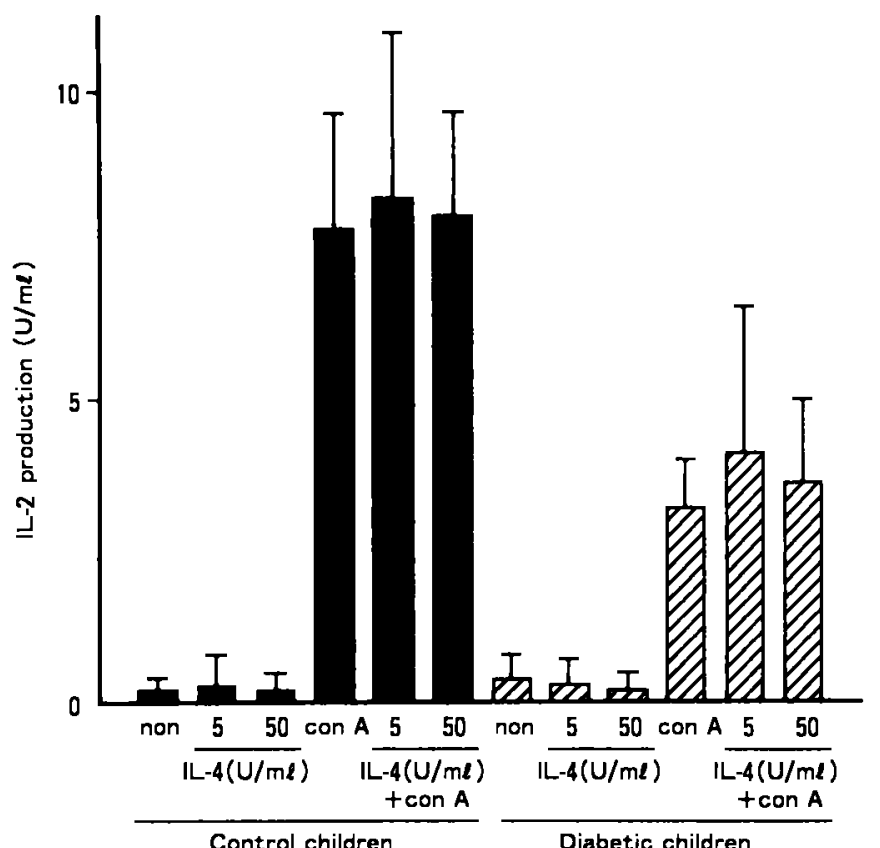

Fig. 6. Effect of IL-4 on IL-2 production. Cells from healthy control and IDDM children were treated with various concentrations of $r-I L-4$ or con A or $r-I L-4$ plus con A. IL-2 production was assayed using an ELISA. Each value represents the means \pm SD of six different preparations

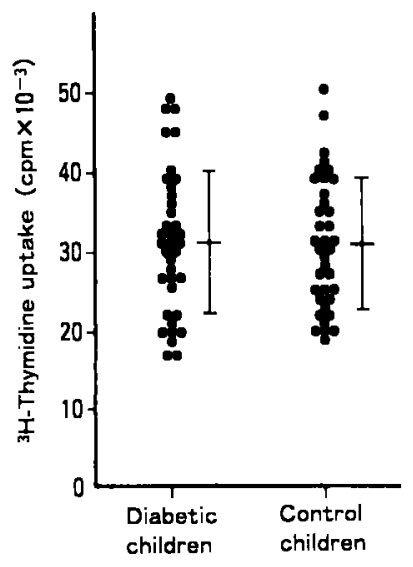

Fig. 7. Response of PMNC to r-IL-2 stimulation in IDDM children $(n=37)$. $5 \times 10^{5} / \mathrm{ml} \mathrm{PMNC}$ were cultured with or without $25 \mathrm{U} / \mathrm{ml}$ r-IL-2 for $48 \mathrm{~h}$. Response to IL-2 is expressed as thymidine uptake $\left(\mathrm{cpm} \times 10^{-3}\right)$. Vertical lines and bars are means $\pm \mathrm{SD}$
Table 3. Responsiveness of $T$ lymphocytes to IL-2

\begin{tabular}{llll}
\hline & \multicolumn{3}{l}{ IL-2 concentration $(\mathrm{U} / \mathrm{ml})$} \\
\cline { 2 - 4 } & 5 & 25 & 125 \\
\hline Control & $1.43 \pm 0.26$ & $3.15 \pm 0.75$ & $3.00 \pm 1.10$ \\
IDDM & $1.35 \pm 0.30$ & $2.87 \pm 0.52$ & $2.73 \pm 0.68$ \\
\hline
\end{tabular}

Proliferative ability of PMNC from healthy control $(n=8)$ and $\operatorname{IDDM}(n=8)$ children in the presence of indicated doses of exgenous r-IL-2 for $48 \mathrm{~h}$. The results are expressed $10^{-3} \mathrm{cpm}$. Each value represents the mean \pm SD from four different preparations

however, at concentrations above $25 \mathrm{U} / \mathrm{ml}$, proliferation plateaued. We therefore used a concentration of $25 \mathrm{U} / \mathrm{ml}$ IL-2 in the subsequent studies.

The response to IL-2 of stimulated T lymphocytes from IDDM children did not differ from that of control T lymphocytes (Fig. 7). In IDDM, there was a close correlation between the response to IL-2 and the IL-2 receptor expression induced by con A stimulation $(r=0.513, p<0.01)$.

\section{Discussion}

During activation, T cells synthesize and secrete IL-2 and express IL-2 receptors. IL-2 binds its receptor, and consequently exerts proliferative effects on activated T cells [14]. IL-2 also contributes to the abrogation of suppressor cell function [9] and to the promotion of helper cell function $[10,19]$. All of these functions have been found to be altered in patients with systemic lupus erythematosis [20]. Furthermore, studies of the mouse strains MRL/1pr and BXSB, which are animal models of lupus erythematosis, have demonstrated that the synthesis of IL-2 is decreased in these animals compared to that in unaffected strains $[21,22]$. These findings suggest that the response to and/or production of IL-2 may be associated with the presence of autoimmune disease. Non-obese diabetic mice, similar to other autoimmune mouse strains, produced small amounts of IL-2, and responded poorly in a syngenic mixed lymphocyte reaction [23]. We therefore studied IL-2 system parameters to determine whether immunological abnormalities and autoimmune phenomena were associated with IDDM. Although the number of $\mathrm{CD}^{+} \mathrm{T}$ cells in IDDM children did not differ from that in control children, activated $\mathrm{CD} 4{ }^{+} \mathrm{T}$ cells in the diabetic children were significantly higher than in the control children. IL-2 synthesis was significantly less in diabetic children, as had been described in previous reports $[11,12]$. Regarding the defective production of IL-2, IL-2 is consumed in abnormal quantities in the presence of high levels of low affinity IL-2 receptors $[24,25]$. However, we found that $T$ lymphocytes in IDDM proliferated in response to r-IL-2 in a concentration-dependent manner at concentrations of less than $25 \mathrm{U} / \mathrm{ml}$, and there was a close correlation be- 
tween the response to IL-2 and the IL-2 receptor expression induced by con $\mathrm{A}$ stimulation. The induced IL-2 receptor therefore seemed to be a high affinity receptor. There was no significant difference between diabetic children and normal control children in con Ainduced IL-2 receptor expression or response to IL-2. These results suggested that IL-2 receptors contributed to the IL-2-driven proliferation of T cells, but that IL-2 production required another signal. Regarding IL-2 system function in IDDM, it is thought that IL-2 production is selectively defective. To clarify the nature of the defect in the level of IL-2 production, we studied IL-2 mRNA, protein and activity. IL-2 mRNA production was found to be lower in IDDM children than in control children. It has been possible, in mice, to identify two functionally distinct subsets of MHC class II-restricted $\mathrm{CD} 4{ }^{+}$helper/inducer T cells, on the basis of IL gene transcription and secretion [26-28]. The Th1 subset secretes IL-2 and IFN- $\gamma$ upon stimulation, while, in contrast, the Th2 subset secretes IL-4 and IL-5. We hypothesized that a change in the proportion of the Th1 and $\mathrm{Th} 2$ subsets of $\mathrm{CD} 4^{+} \mathrm{HLA}-\mathrm{DR}^{+} \mathrm{T}$ cells was associated with IDDM, or that the overproduction of IL-4 suppressed IL-2 production in diabetic patients [29]. We therefore determined IL-4 production by PMNC with and without con A stimulation for both IDDM and control children, and found that a high level of IL-4 was present in diabetic patients. Furthermore, IL-4 did not suppress the IL- 2 and IFN- $\gamma$ production induced by con A stimulation. Thus, it seemed that the IL-2-producing $\mathrm{T}$ cell subset in IDDM was selectively defective. Recently, Rapoport et al. [30] reported that exogenous rIL-4 reversed $T$ cell function in non-obese diabetic mice in vitro and protected against diabetes in vivo. These experiments were performed in the prediabetic stage in an animal model that develops fatal IDDM. Although IDDM in humans and in this model results from $T$ cell-mediated autoimmunity against pancreatic insulin-producing beta cells, the development of the autoimmune state may differ. Although the expression of IL-2 receptors on peripheral T lymphocytes was significantly greater in diabetic than in control children, the sensitivity of T cell IL-2 receptor expression to con A stimulation was similar in the diabetic children and the normal controls. Zielasec et al. [31] reported that administration of IL-2 suppressed the development of diabetes in the high incidence $\mathrm{BB}$ rat. The expression of IL-2 receptors on circulating $\mathrm{T}$ cells seems to required the IL-2 supply, especially in recent onset IDDM children.

Acknowledgements. We thank Ms. M. Matsuda for her help in the preparation of the mansucript. This study was supported, in part, by a grant (C-05807065) from the Ministry of Education, Science and Culture of Japan.

\section{References}

1. Diabetes Epidemiology Research International Group (1988) Geographic patterns of childhood insulin-dependent diabetes mellitus. Diabetes 37: 1113-1119

2. Diabetes Epidemiology Research International Group (1990) Secular trends in incidence of childhood IDDM in 10 countries. Diabetes 39: 858-864

3. Takeo J, Maeda $\mathrm{H}$, Tokunaga $\mathbf{K}$, Ishiba S, Maruyama $\mathrm{H}$ (1984) HLA in Japanese insulin-dependent diabetes mellitus. Acta Pediatr Jpn 26: 289-293

4. Bottazzo GF, Florin-Christensen A, Doniach D (1974) Isletcell antibodies in diabetes mellitus with autoimmune polyendocrine deficiencies. Lancet II: 1279-1283

5. MacCuish AC, Bvarnes EW, Irvine WJ, Duncan LJP (1974) Antibodies to pancreatic islet cells in insulin-dependent diabetics with coexistent autoimmune disease. Lancet II. 1529-1531

6. Eisenbarth GS (1986) Type I diabetes mellitus, A chronic autoimmune disease. N Engl J Med 314: 1360-1368

7. Bottazzo GF, Dean B, McNally J, Mckay E, Swift GF, Gamble D (1985) In situ characterization of autoimmune phenomena and expression of HLA molecules in the pancreas diabetic insulitis. N Engl J Med 313: 353-360

8. Patkau V, Shaw J, Mills G, Caplan B (1980) Cellular origins and targets of costimulator (IL-2). Immunol Rev 51:157-175

9. Palacios R, Moller G (1981) Cell growth factor abrogates concanavalin-A induced suppresser cell function. J Exp Med 153: $1360-1365$

10. Kern D, Gillis S, Okada M, Henney C (1981) The role of interleukin-2 (IL-2) in the differentiation of cytotoxic T cells: the effect of monoclonal anti-IL-2 antibody and absorption with IL-2-dependent T cell lines. J Immunol 127: 13231328

11. Zier KS, Leo MM, Spielman RS, Baker L (1984) Decreased synthesis of interleukin-2 (IL-2) in insulin-dependent diabetes mellitus. Diabetes 33: 552-555

12. Kaye WA, Adri MNS, Soeldner JSI et al. (1986) Acquired defect in interleukin-2 production in patients with type I diabetes mellitus. N EngI J Med 315: 920-924

13. Gillis S, Ferm MM, Ou W, Smith K (1978) T cell growth factor: parameters of production and quantitative microassay for activity. J Immunol 120: 2027-2032

14. Maniatis T, Fritsch EF, Sambrook J (1982) Molecular cloning: laboratory manual. Cold Spring Harbor Laboratory, New York, pp 196-202

15. Davies LG, Dibner MD, Battey JF (1986) Basic methods in molecular biology. Elsevier, New York, pp 143-146

16. Taniguchi T, Matsui H, Fujita T et al. (1983) Structure and expression of a cloned cDNA for human interleukin-2. Nature 302: 305-309

17. Nakajima-Iijima S, Hamada H, Reddy P, Kakunaga T (1985) Molecular structure of the human cytoplasmic B-actin gene: interspecies homology of sequences in the introns. Proc Natl Acad Sci USA 82: 6133-6138

18. Taniguchi T, Yamaguchi K, Yamamoto T et al. (1988) Depression in gene expression for poly (ADP-ribose) synthetase during the interferon-induced activation process of murine macrophage tumor cells. Eur J Biochem 171:571-575

19. Watson JL, Aarden JS, Paetkan V (1979) Molecular and quantitative analysis of helper $T$ cell-replacing factors on the induction of antigen-sensitive B and T lymphocytes. J Immunol 122: $1633-1638$

20. Varela JA, Segovia DA (1981) Decrease production of and response to interleukin-2 by cultured lymphocytes from patients with systemic lupus erythematosus. J Clin Invest 69 : 1388-1392 
21. Altman A, Theofilopoulos AN, Weiner R, Katg D, Dexon F (1981) Analysis of $T$ cell function in autoimmune murine strains. J Exp Med 154: 791-808

22. Wofsy D, Murphy ED, Roths JB, Dauphinee MJ, Kipper SB, Talal N (1981) Deficient interleukin 2 activity in MRL-Mp and C57BL/6J mice bearing the 1 pr gene. J Exp Med 154: $1671-1680$

23. Serreze DV, Leiter EH (1987) Defective activation of T suppressor cell function in nonobese diabetic mice. J Immunol 140: 3801-3807

24. Cavallo MG, Signore A, Baroni MG, Andreani D, Pozzilli P (1989) Interleukin 2 (IL2) production and IL2 receptor release in type I diabetes mellitus. Diabetes Nutr Metab 2: 179-183

25. Lorini R, Montagna D, Lanfranchi A et al. (1989) Alteration of in vitro interleukin 1 and 2 in diabetic children. Eur J Pediatr 148: 732-736

26. Mossmann TR, Cherwinski H, Bond MW, Giodlin MA, Coffman RL (1986) Two type of murine helper T cells. 1. Definition according to profiles of lymphokine activities and secreted proteins. J Immunol 136: 2348-2354
27. Kim J, Woods A, Becker-Dunn E, Bottomly K (1985) Distinct functional phenotypes of cloned Ia-restricted helper T cells. J Exp Med 162: 188-193

28. Boom WH, Liano D, Abbas K (1988) Heterogeneity of helper/inducer $T$ lymphocytes. II. Effect of interleukin-4 and interleukin-2 producing T cell clones on resting B cells. J Exp Med 167: 1350-1357

29. Gaya A, Calle ODL, Yague J et al. (1991) IL-4 inhibits IL-2 synthesis and IL-2-induced up-regulation of IL-2Ra but not IL-2RB chain in CD4 + human T cells. J Immunol 146: 4209 4214

30. Rapoport MJ, Jaramillo A, Zipris D et al. (1993) Interleukin 4 reverses $T$ cell proliferative unresponsiveness and prevents the onset of diabetes in nonobese diabetic mice. J Exp Med 178: 87-99

31. Zielasek J, Burkart V, Naylor P, Goldstein A, Kiesel U, Kolb H (1990) Interleukin 2-dependent control of disease development in spontaneously diabetic BB rats. Immunology 69: 209-214 